\title{
EFEKTIVITAS PEMBELAJARAN ONLINE PADA MATA PELAJARAN SOSIOLOGI DI SMA NEGERI 22 MAKASSAR
}

\author{
Oleh: Santy Ayu Lestari' ${ }^{1}$ Andi Agustang² \\ 12Program Studi pendidikan Sosiologi Fakultas Ilmu Sosial dan Hukum \\ Universitas Negeri Makassar \\ Email: santyalestari@gmail.com ${ }^{1}$,andi.agustang@unm.ac.id ${ }^{2}$
}

\begin{abstract}
Abstrak
Penelitian ini adalah penelitian kuantitatif yang bertujuan untuk mendeskripsikan dan menganalisis pengaruh efektivitas pembelajaran terhadap pembelajaran online pada mata pelajaran sosiologi di SMA Negeri 22 Makassar. Metode yang digunakan dalam penelitian ini adalah kuantitatif dengan pendekatan deskriptif. Teknik sampel dalam penelitian ini menggunakan probability sampling dengan menggunakan simple random sampling, pengumpulan data menggunakan angket dan dokumentasi. Populasi dalam penelitian ini adalah siswa kelas X, XI, dan XII jurusan IPS Tahun ajaran 2020/2021 yang berjumlah 315 orang siswa, sedangkan sampelnya berjumlah 76 responden. Hasil penelitian ini menunjukkan bahwa 1) bentuk efektivitas dari pembelajaran online dapat dilihat dari siswa aktif dalam pembelajaran, siswa tepat waktu dalam mengerjakan tugas dan ulangan yang diberikan oleh guru, tepat waktu hadir dalam pembelajaran, dan respon siswa terhadap kinerja guru sangat baik dalam mengajar pembelajaran online. 2) variabel $X$ (efektivitas pembelajaran) berpengaruh terhadap variabel $\mathrm{Y}$ (pembelajaran online) hal tersebut ditunjukkan dengan nilai signifikan korelasi sebesar 0,619 > 0,05 yang berarti memiliki korelasi hubungan yang kuat. Tingkat signifikansi Rtabel $5 \% \mathrm{~N}=76$ sebesar 0,187 . Jadi o,619 lebih besar dari o,187 dapat disimpulkan bahwa hipotesis nol (Ho) ditolak dan (Ha) diterima. Keeratan hubungan antar variabel dapat dilihat dari koefisien korelasi (tabel correlation atau tabel summary/ nilai R) o,619 dan signifikansi pada nilai o,oo (nilai lebih kecil dari o,05 yang artinya signifikan). Hal ini dapat disimpulkan bahwa terdapat hubungan antar efektivitas pembelajaran terhadap pembelajaran online dengan keeratan hubungannya sebesar 0,619 atau $61,9 \%$ yang dalam kategori hubungan yang kuat.
\end{abstract}

Kata Kunci: Efektivitas Pembelajaran, Pembelajaran Online, Siswa

\section{PENDAHULUAN}

Wabah Covid-19 menghambat manusia dalam beraktivitas sehari-hari. Virus ini awal mulanya berkembang di negara Cina, tepatnya di Wuhan. Penularan dari virus sangat cepat hingga ke berbagai negara sehingga banyak menelan banyak korban jiwa. Dampak penyebaran Covid-19 juga dirasakan oleh Indonesia. Pemerintah mengambil insiatif dalam mencegah penyebaran Covid-19 dengan menerapkan psychal distancing yaitu menjaga jarak diantara masyarakat dan menjauhi segala aktivitas dalam bentuk 
kerumunan serta perkumpulan dengan banyak orang. Selain dengan menerapkan psychal distancing, pemerintah juga menghimbau masyarakat untuk bekerja, belajar, serta beribadah dirumah atau lebih dikenal dengan istilah work from home. Wabah Covid-19 melumpuhkan kegiatan proses belajar mengajar di instansi pendidikan di Indonesia. Oleh karena itu, pemerintah mengeluarkan kebijakan dengan meliburkan atau memindahkan proses pembelajaran siswa di rumah dengan menerapkan metode belajar menggunakan sistem online (daring). Kebijakan pembelajaran online ini di atur dalam SE Mendikbud No.3 Tahun 2020 tentang Pencegahan Covid-19 pada Satuan Pendidikan. (Belawati 2019,h. 6) mengemukakan bahwa pembelajaran online merupakan pembelajaran yang dilakukan melalui jaringan internet. (Belawati 2019,h.67) bahwa istilah online learning banyak disinonimkan dengan istilah lainnya seperti elearning, internet learning, web-based learning, tele-learning, distributed learning, dan lain sebagainya. Meidawati dalam (Pohan 2020,h. 2-3) bahwa: Pembelajaran online dipahami sebagai pendidikan formal yang diselenggarakan oleh sekolah dimana peserta didik dan instrukturnya (guru) berada di tempat berbeda, sehingga memerlukan sistem telekomunikasi interaktif untuk menghubungkan keduanya dan berbagai sumber daya yang diperlukan di dalamnya.

Dari beberapa pendapat para ahli diatas dapat disimpulkan bahwa pembelajaran online adalah salah satu pembelajaran jarak jauh yang menggunakan teknologi atau internet dalam pelaksanaan pembelajarannya. Problematika saat ini adalah berdasarkan fenomena yang terjadi pada proses pembelajaran online belum sepenuhnya diterapkan sesuai dengan arahan Menteri Pendidikan dan Kebudayaan untuk menerapkan pembelajaran bermakna. Hal ini tidak dapat disalahkan sebab memang kondisi yang serba mendadak dan diluar dugaan. Selain itu, belum adanya persiapan yang matang dan panduan pembelajaran online yang dimiliki oleh guru-guru. Adanya Covid-19 ini, memaksa kesiapan guru sebagai aktor utama dalam memberikan pembelajaran, kesiapan sekolah, kesiapan siswa pembelajaran, keterlibatan orangtua serta kebijakan dari pemerintah untuk menjamin kondisi pembelajaran agar berjalan dengan baik. Namun kondisi pembelajaran belum dapat berjalan secara optimal sebagaimana halnya pembelajaran langsung di dalam kelas. Terdapat banyak kendala yang dihadapi guru dalam pembelajaran, begitupun juga dengan siswa. Hal ini disebabkan berbagai faktor yang melatarbelakanginya. Hal yang sama juga dirasakan oleh orangtua siswa yang terkendala pada besarnya jumlah biaya untuk mengikuti pembelajaran online ini.

Empat kemampuan profesionalitas guru, penguasaan materi dan sikap guru diuji saat masa pandemi Covid-19 terjadi. SMA Negeri 22 Makassar merupakan salah satu sekolah yang menerapkan pembelajaran online sejak mulai diberlakukannya work from home kepada siswanya. Media online yang digunakan seperti microsoft team dan whatsapp group. Materi yang diberikan dalam bentuk video singkat, powerpoint, dan bahan bacaan. Namun dalam pelaksanaan pembelajaran online tersebut proses pembelajaran saat ini masih terbatas pada pemberian tugas kepada peserta didik 
melalui media belajar online. Bahkan hal ini dapat membuat siswa merasa tertekan dengan tugas-tugas yang banyak dengan tenggang waktu yang terbatas. Sementara itu, pembelajaran sosiologi mensyaratkan proses interaksi sosial dalam pembelajaran dan masyarakat sebagai objek kajian pembelajaran.

\section{METODE PENELITIAN}

Jenis penelitian ini adalah kuantitatif dengan pendekatan deskiptif yaitu data yang digunakan untuk menjelaskan suatu gejala atau fenomena yang terjadi dalam bentuk angka-angka. Dalam penelitian ini mengambil lokasi di SMA Negeri 22 Makassar yang berlokasi di Jl. Pajjaiang, KOMP KOR KNPI, Biringkanaya, Sudiang Raya, Kota Makassar, Sulawesi Selatan. (Agustang 2011,h. 4) bahwa penelitian biasanya dihadapkan pada penentuan hubungan sebab-akibat jawaban terhadap pertanyaan hubungan sebab-akibat penting untuk keperluan meramalkan, kontrol di satu pihak, dan verstehen (pengertian interpretative mengenai manusia) dilain pihak. Paradigma ilmiah membatasi diri pada pengetahuan demikian merupakan esensi metode untuk menyatakan proporsi secara eksplisit dalam bentuk hipotesis yang diuji validitasnya.

Definisi populasi menurut (Sugiyono 2013, h.80) bahwa populasi adalah wilayah generalisasi yang terdiri atas obyek atau subyek yang mempunyai kualitas dan karakteristik tertentu yang ditetapkan peneliti untuk dipelajai kemudian ditarik kesimpulannya. Populasi dalam penelitian ini adalah siswa kelas X, XI, dan XII IPS SMA Negeri 22 Makassar yang berjumlah 315 siswa.

Sampel merupakan sebagian dari populasi yang diambil dengan cara teknik tertentu atau metode tertentu yang membentuk kesimpulan terhadap populasi. Teknik sampel dalam penelitian ini adalah probability sampling dengan menggunakan teknik sampling acak sederhana (Simple Random Sampling). Alasan pengambilan probability sampling karena pengambilan sampel ini memberikan peluang yang sama bagi setiap unsur populasi untuk dipilih menjadi anggota sampel. Penggunaan teknik simple random sampling dilakukan secara acak tanpa memperhatikan strata yang ada dalam populasi tersebut. Karena populasi dalam penelitian ini diketahui, maka dalam pengambilan jumlah sampel peneliti menggunakan rumus dari Slovin. Sehingga dari populasi yang berjumlah 315 siswa, diperoleh sampel sebanyak 76 orang siswa. Teknik pengumpulan data melalui kuesioner/angket dan dokumentasi. Teknik analisis data menggunakan uji prasyarat analisis (uji normalitas dan regresi sederhana).

\section{PEMBAHASAN}

\section{Efektivitas Pembelajaran Terhadap Pembelajaran Online Pada Mata Pelajaran Sosiologi Di SMA Negeri 22 Makassar}

Dalam pendidikan, pembelajaran online merupakan sebuah pilihan agar proses belajar mengajar tetap berjalan di tengah pandemi Covid-19. Meidawati dalam(dalam Pohan 2020,h. 2-3) mengatakan bahwa pembelajaran online sebagai pendidikan formal dimana siswa dan guru berada di tempat yang berbeda yang memerlukan sistem 
telekomunikasi interaktif untuk menghubungkan keduanya serta sumber daya yang diperlukan di dalamnya. Sementara menurut Bates dalam Rosmita, Suratno, and Nasori 2020, h. 56) bahwa pembelajaran online merupakan bentuk dari pendidikan jarak jauh dimana penyampaian materinya dilakukan melalui internet. (Pohan 2020) juga menyatakan bahwa pembelajaran yang efektif tidak terlepas dari peran guru yang efektif, kondisi pembelajaran yang efektif, keterlibatan siswa, dan lingkungan belajar yang mendukung.

Berdasarkan data hasil angket yang telah diperoleh peneliti mengenai efektivitas pembelajaran terhadap pembelajaran online pada mata pelajaran sosiologi siswa di SMA Negeri 22 Makassar. Keefektivan pembelajaran dapat diukur dari segi keaktifan siswa. Peneliti menemui bahwa pembelajaran online meningkatkan kepercayaan diri siswa, jika biasanya siswa malu untuk bertanya kepada guru, maka dalam pembelajaran online siswa yang pemalu akan lebih percaya diri dan aktif bertanya kepada guru dan berani mengemukakan pendapat. Selain itu, pemberian materi melalui slide power point yang dibuat menarik membuat siswa senang memperhatikan pembelajaran daripada buku. Bahkan tak jarang siswa meminta file power point kepada guru untuk dipelajari ulang dirumah.

Selanjutnya keefektivan pembelajaran dari segi nilai siswa. Pada pembelajaran online sebagian besar siswa yang hadir dalam mengerjakan tugas dan ulangan yang diberikan guru tepat waktu. Meskipun beberapa siswa masih tidak tepat waktu dalam mengumpulkan, tetapi guru mata pelajaran sosiologi terus berusaha memberikan kemudahan dan kesempatan kepada siswa untuk dapat mengumpulkan tugas dan ulangan dengan tujuan agar siswa mendapatkan nilai perolehan hasil belajar. Keefektivan pembelajaran dari segi kehadiran siswa. Sebagian besar siswa hadir tepat waktu dalam kelas virtual. Meskipun masih terdapat beberapa siswa yang tidak tepat waktu hadir dalam kelas. Hal ini dikarenakan oleh faktor sinyal atau koneksi yang menjadi faktor penting dalam pembelajaran online. Meskipun demikian, guru mata pelajaran sosiologi masih tetap memberikan kesempatan kepada siswa yang terlambat hadir untuk dapat ikut dalam proses pembelajaran.

Selanjutnya keefektivan pembelajaran dari segi kinerja guru. Berdasarkan data angket siswa terhadap kinerja guru dalam proses pembelajaran online, yaitu guru hadir tepat waktu dalam mengajar, menjelaskan materi dengan baik sehingga mudah dipahami. Cara guru memberikan penilaian terhadap tugas dan ulangan bersifat objektif dan terbuka. Hal ini ditandai dengan adanya tugas dan ulangan yang dikoreksi oleh guru dibagikan kepada siswa dengan komentar. Pemberian komentar dengan pujian akan memberikan dorongan motivasi kepada siswa dalam pembelajaran online. Kecepatan akses internet menjadi salah satu faktor pendukung dalam pembelajaran online. Siswa dapat lebih mudah dalam mencari materi pelajaran melalui internet selain 
materi yang ada pada buku. Selain itu, siswa dapat lebih mudah dalam mengerjakan tugas-tugas yang diberikan oleh guru.(Anas,dkk 2014)

Namun terdapat kendala dalam proses pembelajaran online yaitu masalah jaringan sehingga mengganggu proses belajar. Selain jaringan, masalah kuota internet juga menjadi kendala (Gusty et al. 2020). Banyak siswa yang mengeluhkan tentang pembelajaran online yang membuat mereka boros karena dana yang harus dikeluarkan untuk pembelajaran online cukup banyak. Salah satu media yang digunakan dalam pembelajaran online adalah handphone dan atau laptop. Penggunaan handphone atau laptop memudahkan siswa dan guru dalam berkomunikasi dan mempermudah siswa dan guru dalam mengirim tugas dan ulangan, mengingat kondisi yang pandemi tidak bisa untuk tatap muka. Jika pun siswa tidak mempunyai handphone atau laptop, siswa biasanya bergabung dengan teman yang punya sehingga proses belajar tidak terhambat. Penggunaan handphone dalam belajar online juga terdapat kendala, yaitu adanya notifikasi-notifikasi dari handphone yang terkadang muncul selama proses pembelajaran sehingga membuat siswa menjadi kurang fokus dalam belajar.

Dalam pembelajaran online di SMA Negeri 22 Makassar, media pembelajaran yang digunakan adalah whatsapp dan microsoft team. Menurut Enterprise (2012, h. 1) bahwa whatsapp merupakan aplikasi chatting yang dapat mengirim pesan teks, gambar, suara, lokasi, dan bahkan video dengan menggunakan ponsel. Sedangkan menurut Microsoft dalam(Widiyarso and Sutama 2021, h.17) menyatakan bahwa microsoft team adalah aplikasi cloud yang menyatukan percakapan, rapat, file, dan aplikasi dalam satu Sistem Manajemen Pembelajaran (LMS) tunggal. Penggunaan aplikasi whatsapp dan microsoft team dimanfaatkan oleh guru di SMA Negeri 22 Makassar untuk mempermudah proses pembelajaran online saat ini. Berdasarkan data hasil angket, penggunaan aplikasi whatsapp dan microsft team memudahkan siswa dan guru untuk berdiskusi tentang materi pelajaran, memudahkan untuk mengirim tugas dan ulangan yang diberikan guru. Selain itu fitur conference dalam aplikasi microsft team memudahkan siswa untuk saling berinteraksi dengan guru dan teman kelas saat pembelajaran online. Siswa juga dapat mudah melihat hasil tugas maupun ulangan yang telah dinilai oleh guru.

\section{Pengaruh Efektivitas Pembelajaran Terhadap Pembelajaran Online Pada Mata Pelajaran Sosiologi}

Hasil penelitian ini menunjukkan pengaruh efektivitas pembelajaran terhadap pembelajaran online siswa pada mata pelajaran sosiologi. Hal ini ditunjukkan dengan signifikan sebesar 0,837 dan berdasarkan pedoman interpretasi koefisien korelasi berada pada interval koefisien $(0,80-1,000)$ yang berarti memiliki tingkat hubungan sangat kuat. Hasil analisis uji t sebesar 6,782 sehingga dapat diketahui bahwa ada pengaruh yang signifikan antara variabel efektivitas pembelajaran (X) terhadap 
pembelajaran online (Y). Hal ini dilakukan dengan hasil perhitungan uji $\mathrm{F}$ pada tabel 4.13 menunjukkan nilai signifikan $0,000<0,05$ yang berarti terdapat hubungan antar variabel $\mathrm{X}$ dan variabel $\mathrm{Y}$. Sedangkan nilai $\mathrm{R}$ pada tabel Model Summary yaitu menunjukkan $r_{\text {hitung }} 0,619>r_{\text {tabel }}$ 0,05 yang berarti memiliki korelasi hubungan yang kuat. Sedangkan pada t tabel adalah 4,940 dan nilai signifikansi o,ooo dengan taraf signifikansi $5 \%$ yang dapat disimpulkan bahwa Ha diterima yaitu: Ada pengaruh signifikan antara efektivitas pembelajaran terhadap pembelajaran online pada mata pelajaran sosiologi di SMA Negeri 22 Makassar dan menolak Ho : tidak ada pengaruh yang signifikan antara efektivitas pembelajaran terhadap pembelajaran online pada mata pelajaran sosiologi di SMA Negeri 22 Makassar. Hal ini ditunjukkan bahwa nilai koefisien determinasi yang diperoleh adalah $38,3 \%$. Sehingga dapat disimpulkan bahwa variabel bebas $\mathrm{X}$ memiliki pengaruh kontribusi sebesar $38,3 \%$ terhadap variabel terikat $\mathrm{Y}$, sedangkan sisanya $61,7 \%$ diperngaruhi oleh faktor lain. Hasil penelitian ini sejalan dengan penelitian (Mustakim 2020) dan (Agustang 2011) yang menyatakan bahwa hasil penelitian menggambarkan peserta didik menilai pembelajaran matematika menggunakan media online sangat efektif (23,3\%), sebagian besar mereka menilai efektif (46,7\%), dan menilai biasa saja (20\%). Meskipun ada juga peserta didik yang menganggap pembelajaran daring tidak efektif (10\%) dan sama sekali tidak ada (0\%) yang menilai sangat tidak efektif. Berdasarkan uraian tersebut, terdapat persamaan dengan penelitian ini yaitu pembelajaran online sangat efektif menggunakan metode dan media pembelajaran yang sesuai dengan materi pembelajaran agar pembelajaran yang disampaikan tidak terasa membosankan.

\section{PENUTUP}

Berdasarkan hasil penelitian yang telah diuraikan pada bab sebelumnya maka dapat disimpulkan bahwa bentuk efektivitas dari pembelajaran online dapat dilihat dari siswa aktif dalam pembelajaran, siswa tepat waktu dalam mengerjakan tugas dan ulangan yang diberikan oleh guru, tepat waktu hadir dalam pembelajaran, dan respon siswa terhadap kinerja guru sangat baik dalam mengajar pembelajaran online. Media daring yaitu aplikasi whatsapp dan microsoft team yang menjadi media pembelajaran di SMA Negeri 22 Makassar sudah membantu mempermudah guru dan siswa dalam proses pembelajaran. Tidak hanya whatsapp dan microsoft team, tetapi diharapkan guru juga bisa menggunakan media pembelajaran yang lain agar pengetahuan guru dan siswa mengenai media pembelajaran online dapat terus bertambah. Efektivitas pembelajaran online akan terbangun ketika berbagai komponen pendidikan saling berintegrasi. Meskipun masih terdapat kendala yang ditemukan untuk itu diperlukan kerja sama yang saling mendukung untuk bersama-sama menciptakan efektivitas dan pembelajaran yang menyenangkan di tengah pandemi Covid-19. 
Selanjutnya nilai pada t tabel adalah 4,940 dan nilai signifikansi o,ooo dengan taraf signifikansi $5 \%$ yang dapat disimpulkan bahwa Ha diterima yaitu: Ada pengaruh signifikan antara efektivitas pembelajaran terhadap pembelajaran online pada mata pelajaran sosiologi di SMA Negeri 22 Makassar.

\section{DAFTAR PUSTAKA}

Agustang, Andi. 2011. Pendekatan Penelitian Kualitatif Dan Kuantitatif Suatu Tinjauan Kritis. Makassar: Andira Publisher.

Agustang, A. Y. A., Herman, H., Said, M., \& Agustang, A. (2021). Upaya Guru IPS Dalam Meningkatkan Motivasi Belajar Siswa Pada Masa Covid 19 Di SMP. Phinisi Integration Review, 4(1), 144-149.

Agustang, A. (2021, January 22). Filosofi Research Dalam Upaya Pengembangan Ilmu. https://doi.org/10.31219/osf.io/9n6za

Anas, Muhammad, and M. PdI. 2014. Mengenal Metodologi Pembelajaran. Muhammad Anas. Belawati, Tian. 2019. Pembelajaran Online.Jakarta, Universitas Terbuka.

Enterprise, Jubilee. 2014. Chatting Tanpa Batas Menggunakan Whatsapp. Elex Media Komputindo.

Gusty, Sri, Nurmiati Nurmiati, Muliana Muliana, Oris Krianto Sulaiman, Ni Luh Wiwik Sri Rahayu Ginantra, Melda Agnes Manuhutu, Andriasan Sudarso, Natasya Virginia Leuwol, Apriza Apriza, and Andi Arfan Sahabuddin. 2020. Belajar Mandiri: Pembelajaran Daring Di Tengah Pandemi Covid-19. Yayasan Kita Menulis.

har, M., Agustang, A., Adam, A., \& Upe, A. (2021). Online Learning and Distortion of Character Education in the Covid-19 Pandemic Era. Webology, 18(Special Issue 04), 566-580. https://doi.org/10.14704/web/v18sio4/web18149

Mustakim, Mustakim. 2020. "Efektivitas Pembelajaran Daring Menggunakan Media Online Selama Pandemi Covid-19 Pada Mata Pelajaran Matematika." Al Asma: Journal of Islamic Education 2(1):1-12.

Pohan, Albert Efendi. 2020. Konsep Pembelajaran Daring Berbasis Pendekatan Ilmiah.

Penerbit CV. Sarnu Untung.

Ramlafatma, R., Oruh, S., \& Agustang, A. (2021). Efektivitas Pendidikan Moral Dalam Pembentukan Karakter Siswa Di TK Islam Terpadu Asa Sumbawa. Jurnal Ilmiah Mandala Education, 7(4).

Rosmita, Rosmita, Suratno Suratno, and Ahmad Nasori. 2020. "Efektivitas Pembelajaran Daring (Studi Kasus Hasil Belajar Mata Pelajaran Ekonomi Kelas X IPS SMA Negeri 9 Tanjung Jabung Timur Tahun 2019/202O).”

Sugiyono, Dr. 2013. "Metode Penelitian Pendidikan Pendekatan Kuantitatif, Kualitatif Dan R\&D.”

Widiyarso, Tri Hanung, and Sutama Sutama. 2021. "Efektifitas Penggunaan Microsoft Teams Dalam Pembelajaran E-Learning Bagi Guru Selama Pandemi Covid19." Didaktis: Jurnal Pendidikan Dan Ilmu Pengetahuan 21(1).

Bebang, M., \& Agustang, A. (2021). THE SOCIAL ACTION OF THE TEACHERS IN HANDLING INDISIPLINARY STUDENTS AT SMP NEGERI 36 MAKASSAR, SOUTH SULAWESI, INDONESIA. 2O(5), 5792-5796. https://doi.org/10.17051/ilkonline.2021.05.652 